U. S. DEPARTMENT OF COMMERCE BUREAU OF STANDARDS

\title{
STAPLE SEATS \\ FOR WATER-CLOSET BOWLS
}

COMMERCIAL STANDARD CS29-31

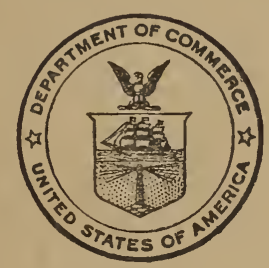

\section{A RECORDED STANDARD} OF THE INDUSTRY 
Below are described some of the series of publications of the Department of Commerce which deal with various phases of waste elimination.

\section{Simplified Practice Recommendations.}

These present in detail the development of programs to eliminate unnecessary variety in sizes, dimensions, styles, and types of over 100 commodities. They also contain lists of associations and individuals who have indicated their intention to adhere to the recommendations. These simplified schedules, as formulated and approved by the industries, are indorsed by the Department of Commerce.

\section{American Marine Standards.}

These are promulgated by the American Marine Standards Committee, which is controlled by the marine industry and administered as a unit of the division of simplified practice. Their object is to promote economy in construction, equipment, maintenance, and operation of ships. In general, they provide for simplification and improvement of design, interchangeability of parts, and minimum requisites of quality for efficient and safe operation.

\section{Commercial Standards.}

These are developed by various industries under a procedure similar to that of simplified practice recommendations. They are, however, primarily concerned with considerations of grade, quality, and such other characteristics as are outside the scope of dimensional simplification.

Lists of the publications in each of the above series can be obtained by applying to the National Bureau of Standards, Washington, D. C. 


\title{
U.S. DEPARTMENT OF COMMERCE
}

R. P. LAMONT, Secretary

BUREAU OF STANDARDS

GEORGE K. BURGESS, Director

\section{STAPLE SEATS}

\section{FOR WATER-CLOSET BOWLS}

\section{COMMERCIAL STANDARD CS29-31}

\author{
Effective Date for New Production and Clearance \\ of Existing Stocks October 1, 1931
}

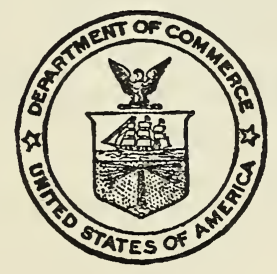

UNITED STATES

GOVERNMENT PRINTING OFFICE

WASHINGTON : 1931

For sale by the Superintendent of Documents, Washington, D. C. - - - Price 5 conts 


\section{CONTENTS}

Acceptors

Commercial standard

General

Nomenclature

Materials and constructions

Dimensions

Finishes_......-.

Hinges

Labels and guarantees

General conference.

Standing committee.

Effective date.....-.

Certification plan

Commercial standards service.

Organization and duties of standing committee Your cooperation

Acceptance of commercial standard

To the acceptor

Request for commercial standards

List of commercial standards 


\section{STAPLE SEATS FOR WATER-CLOSET BOWLS, CS29-31}

\section{ACCEPTORS}

ASSOCIATIONS

American Society of Sanitary Engineering, Washington, D. C. (in principle).

Business Service Bureau of the Plumbing \& Heating Industries, Chicago, Ill. (in principle).

Eastern Supply Association, New York, N. Y.

Illinois Master Plumbers' Association, Chicago Heights, Ill.

National Association of Master Plumbers of the U. S. (Inc.), New York, N. Y. (in principle).

Plumbers Woodwork Institute, Pittsburgh, $\mathrm{Pa}$.

\section{FIRMS}

Abingdon Sanitary Manufacturing Co., Abingdon, Ill.

Abramson, Nathan, Washington, D. C. Adkins, Young \& Allen Co., Chicago, Ill. Ahlbach \& Mayer, San Francisco, Calif. American Plumbing Manufacturing Cos., Woodside, Long Island, N. Y.

American Tin \& Terne Plate Co., Philadelphia, Pa.

Architects League of Northern New Jersey, Cliffside Park, N. J.

Baker Plumbing Co. (Inc.), Beaumont, Tex.

Bard, Mohler M., Lancaster, Pa.

Basche-Sage Hardware Co., Baker, Oreg.

Beckenstein (Inc.), E., New York, N. Y.

Becker Manufacturing Co., The, Marietta, Ohio.

Beneke Manufacturing Co., Chicago, III.

Bethlehem Shipbuilding Corporation (Ltd.), Quincy, Mass.

Biggs-Kurtz Hardware Co., Grand Junction, Colo.

Biggs Pump \& Supply Co., Lafayette, Ind.

Blackwell Wielandy Co., St. Louis, Mo.

Blake-Rounds Supply Co., Portland, Me.

Boiton, George W., Coral Gables, Fla. B. O. T. Manufacturing Co., Trenton, N. J.

Bourneuf Corporation, Louis, Lynn, Mass.

Bowlen \& Price, Logansport, Ind.
Bowman Supply \& Manufacturing Co. (Inc.), North Side, Pittsburgh, Pa.

Bradley Co., J. R., Reno, Nev.

Braman, Dow \& Co., Boston, Mass.

BRE Manufacturing Co., Hyde Park, Mass.

Bridgeport Plumbing Supply Co. (Inc.) Bridgeport, Conn.

Brunswick Balke Collender Co., Chicago, Ill.

Bumsteads, Heating \& Plumbing, Colorado Springs, Colo.

Bushnell Pump Co., Bushnell, Ill.

Callis, jr., George R., Catonsville, Md.

Camlet, J. Thomas, Clifton, N. J.

Canfield Supply Co., Kingston, N. Y.

Carl's Sheet Metal Works, Charleston, S. C.

Carmichael, C. V., Monitor, Oreg.

Cedar Rapids Pump \& Supply Co., Cedar Rapids, Iowa.

Central Metal \& Supply Co., Baltimore, Mid.

Central Plumbing Supply Co., Bridgeport, Conn.

Chandler Pump Co., Cedar Rapids, Iowa.

Chandler Pump \& Supply Co., Kansas City, Mo.

Channel Co., Long Beach, Calif.

Chapman Co., The, Detroit, Mich.

Church Manufacturing Co., C. F., Holyoke, Mass.

City of Detroit, Department of Water Supply, Dearborn, Mich.

Coyne \& Delany Co., Brooklyn, N. Y.

Crane Co., Columbus, Ohio.

Crocker Chair Co., Sheboygan, Ohio.

Dalton Supply Co., Clarks Summit, $\mathrm{Pa}$.

Dalziel Moller Co., San Francisco, Calif.

Davies Supply Co., The, Chicago, Ill. Dayton Supply Co., The, Dayton, Ohio.

Depue, C. J., Towanda, Pa.

Deutz \& Bro., A., Laredo, Tex.

Diamond Match Co., The, Oswego, N. Y.

Dixon \& Ballou (Inc.), Buffalo, N. Y.

Doody's Plumbing \& Heating Supplies, Philadelphia, Pa.

Douglas Co., The John, Cincinnati, Ohio.

Drake (Inc.), George H., Buffalo, N. Y. Dubuque Supply Co., R. A., St. Louis, Mo.

Eljer Co., Ford City, Pa. 
Eljer Ohio Co., Cleveland, Ohio.

Fall River Steam \& Gas Pipe Co. Corporation, Fall River, Mass.

Ferguson Supply Co., Grand Rapids, Mich.

Fleck Bros. Co., Philadelphia, Pa.

Florida Automobile \& Gas Engine Co., Tampa, Fla.

Geddes Co., Henry B., West Orange, N. J.

Gehri Heating \& Plumbing Co. (Inc.), Tacoma, Wash.

Germain Manufacturing Co., Saginaw, Mich.

Goeddel, A. C., San Diego, Calif. (in principle).

Goss Co., The C. H., St. Johnsbury, Vt.

Grubb, H. D., Lexington, Ill.

Haas Co., The Philip, Dayton, Ohio.

Hajoca Corporation, Philadelphia, Pa.

Hall \& Knight Hardware Co., Lewiston, $\mathrm{Me}$.

Hallberg \& Co., L. G., Chicago, Ill.

Hallsted, H. E., Hay Springs, Nebr.

Harris Pump \& Supply Co., Pittsburgh, $\mathrm{Pa}$.

Hazleton Machinery \& Supply Co. (Inc.), Hazleton, $\mathrm{Pa}$.

Healey Pottery Co., Trenton, N.J.

Heap \& Sons, William, Grand Haven, Mich.

Hermitage Engineering Co., Nashville, Tenn.

Higbro Engineering Co., Wellington, Kans.

Hillman Plumbing Co., McCamey, Tex.

Howe Supply Co., W. B., St. Joseph, Mo.

Hubbard Co., The S. B., Jacksonville, Fla.

Hughes \& Co., Spokane, Wash.

Hughes Supply Co., The, Mansfield, Ohio.

Hunter \& Co., Alfred J., Muskegon, Mich.

Hussey \& Son, W. H., New York, N. Y.

Ideal Supply Co., Somerville, Mass.

Ihler, J. P., Spokane, Wash.

Inland Pipe \& Supply Co., Yakima, Wash.

Interstate Hardware \& Supply Co., Bristol, Va.

"I-X-L" Pump \& Manufacturing Co. (Inc.), The, Philadelphia, Pa.

Johnson, G. W., Berwick, Pa.

Johnson Co., J. D., Pensacola, Fla.

Judd Corporation, Earl, Chicago, Ill.

Kalispell Mercantile Co., Kalispell, Mont.

Keiser-Van Leer Co., The, Bloomington, Ill.

Kennedy-McCandless Cor p o r a ti o n, Rochester, N. Y.

Kinsey \& Mahler Co., Peoria, Ill.

Klink \& Co., N. S., Phoenix, Ariz.

Koepsell Co., J. J., Sheboygan, Wis.
Kohler Co., Kohler, Wis.

Kokomo Supply Co., Kokomo, Ind.

Lansing Supply Co., Lansing, Mich.

Larson \& Son, G. A., Chicago, Ill.

Leighton Supply Co., Fort Dodge,Iowa.

Liggett \& Sons, J. A., Kansas City, Mo.

Lorick \& Lowrance, (Inc.), Columbia, S. C.

Ludington (Inc.), E. A., New Rochelle, N. Y.

Luzerne Rubber Co., The, Trenton, N. J.

Macy \& Co. (Inc.), R. H., New York, N. Y.

Malone Plumbing Supply Co., Pittsburgh, $\mathrm{Pa}$.

May Supply Co., Anderson, Ind.

McArdle \& Cooney (Inc.), Philadelphia, $\mathrm{Pa}$.

McKenna, James H., Savannah, Ga.

Mercedes Plumbing Co., Mercedes, Tex.

Merkel Bros. Co., The, Cincinnati, Ohio.

Michigan Supply Co., Lansing, Mich.

Mid-States Rubber Co., Evansville, Ind.

Miller Supply Co., Chicago, Ill.

Milwaukee Plumbing \& Heating Supply Co., Milwaukee, Wis.

Missoula Mercantile Co., Missoula, Mont.

Missouri Water \& Steam Supply Co., St. Joseph, Mo.

Modern Utilities Co., Harrisburg, Pa.

Mohican Pottery Co., Philadelphia, $\mathrm{Pa}$.

Mueller Co., Decatur, Ill.

Murray \& Alder (Inc.), Hackensack, N. J.

Murray, H. M., Port Chester, N. Y.

Nailon Corporation, Peoria, Ill.

National Mill Supply Co., Fort Wayne, Ind.

Nelson Co., Detroit, Mich.

Nelson Manufacturing \& Supply Co., Hutchinson, Kans.

Nelson Manufacturing Co., N. O., Edwardsville, Ill.

Nelson Manufacturing Co., N. O., St. Louis, Mo.

Never Split Seat Co., Evansville, Ind.

New Freedom Hardware Co., New Freedom, Pa.

New Jersey Engineering \& Supply Co., Passaic, N. J.

New Kensington Sanitary Pottery (Inc.), New Kensington, Pa.

New Process Fibre Corporation, Freeport, Me.

Norfolk \& Western Railway Co., Roanoke, Va.

North Philadelphia Supply Co. (Inc.), Philadelphia, Pa.

Norwich Plumbing Supply House (Inc.), Norwich, Conn.

Oehrle, William, New York, N. Y.

Olson, Ben, Tacoma, Wash.

Orange County Plumbing Supply Co. (Inc.), Middletown, N. Y. 
Pacific Plumbing \& Heating Supply Co., San Francisco, Calif.

Peerless Pennsylvania Co. (Inc.), Philadelphia, $\mathrm{Pa}$.

Peerless-Tulsa Co., Tulsa, Okla.

Peerless-Utah Co., Salt Lake City, Utah.

Perth Amboy Hardware Co., Perth Amboy, N. J.

Pettis, John R., Los Angeles, Calif.

Piers, Eber F., Ogden, Utah.

Pitt \& Co., Walter A., Bloomfield, N. J.

Pleasantville Plumbing Supply Co., Pleasantville, N. J.

Plumbers Supply Co. of St. Louis, St. Louis, Mo.

Potomac Pottery Co., Keyser, W. Va.

Providence Plumbing Supply Co., Providence, R. I.

Quogue Plumbing Co., Quogue, Long Island, N. Y.

Rayl Co., The, Detroit, Mich.

Reddington \& Judge, Scranton, $\mathrm{Pa}$.

Richmond Sanitary Co. (Inc.), San Francisco, Calif.

Rockford Plumbing Supply Co., Rockford, Ill.

Rom Co., The Robert, Milwaukee, Wis.

Roosevelt Co., W. A., La Crosse, Wis. Salt Lake Hardware Co., The, Salt Lake City, Utah.

Sanitary Engineers Supply Co., The, Cleveland, Ohio.

Sanitary Plumbing Supply Co., Jersey City, N. J.

Sanitary Specialties Co. (Inc.), Philadelphia, Pa.

Shannon, George H., Watsontown, Pa.

Sheller Manufacturing Corporation, Portland, Ind.

Sherwood Brass Works, Detroit, Mich.

Shwab Bros. Co., New York, N. Y.

Smith \& Abbott Co., The, Portland, Me.

Smith Co., The H., Fair Haven, N. J.

Speakman Co., Wilmington, Del.

Standard Sanitary Manufacturing Co., Pittsburgh, $\mathrm{Pa}$. (in principle).

Standard Supply \& Equipment Co. of Pennsylvania, Altoona, $\mathrm{Pa}$.

Standard Supply \& Hardware Co. (Inc.), New Orleans, La.

Standard Tank \& Seat Co., Camden, N. J.

Steele \& Sons Co., Wm., Philadelphia, $\mathrm{Pa}$.

Stone Supply Co., The, Portland, Oreg. Street, W. V., Wichita, Kans.

Sturgis Supply Co., Sturgis, Mich.

Sullivan County Plumbing \& Heating Supplies Co. (Inc.), Liberty, N. Y.
Summers Hardware Co., Johnson City, Tenn.

Synwood (Inc.), Cleveland, Ohio.

Tay-Holbrook Co., San Francisco, Calif.

Tennessee Mill \& Mine Supply Co. Knoxville, Tenn.

Thayer Supply Co., Atchison, Kans.

Trant \& Bro., Thomas, Hartford, Conn.

Treaty Co., The, Greenville, Ohio.

Trenton Potteries Co., The, Trenton, N. J.

Trimble \& Lutz Supply Co., Wheeling, W. Va.

Trumbull Plumbing Supply Co., Warren, Ohio.

Tyler, Fred W., Lincoln, Nebr. (in principle).

Tyne Co., Chicago, Ill.

Union Pacific System (Oregon Short Line R. R. Co.), Salt Lake City, Utah.

U. S. Supply Co., Kansas City, Mo.

Universal Sanitary Manufacturing Co., New Castle, $\mathrm{Pa}$.

Universal Supply Co., The, Newark, Ohio.

Wagner \& Sons, Michael, Chicago, Ill.

Warren Balderston Co., Trenton, N. J.

Watrous Co., The, Chicago, Ill.

Weaks Supply Co., Monroe, La.

Weil-McLain Co., Chicago, Ill.

Westchester Square Plumbing Supply Co., Bronx, New York, N. Y.

Western Electric Co. (Inc.), New York, N. Y. (in principle).

Western Supply Co., Lincoln, Nebr.

West Virginia Heating \& Plumbing Co., Charleston, W. Va.

Wheatland Co. (Inc.), Cedar Rapids, Iowa.

White \& Shauger (Inc.), Paterson, N. J.

Whitney \& Ford Co., Chicago, Ill.

Wigman Co., Sioux City, Iowa.

Williams Hardware Co., The, Clarksburg, W. Va.

Worthen Co., A. B., Methuen, Mass.

Worthington Co., The George, Cleveland, Ohio.

Wynkoop, Joseph, Narberth, Pa. (in principle).

Yelton-Weaver Supply Co., Springfield, Ill.

Young Supply Co., W. B., Kansas City, Mo.

\section{GOVERNMENT}

District of Columbia Municipal Architect's Office, Washington, D. C.

United States Treasury Department, Washington, D. C.

War Department, Construction Division, Washington, D. C. 



\section{STAPLE SEATS FOR WATER-CLOSET BOWLS}

\section{COMMERCIAL STANDARD CS29-31}

On December 10, 1930, a general conference of representative manufacturers, distributors, and buyers of staple seats for water-closet bowls adopted a commercial standard for this commodity. The industry has since accepted and approved for promulgation by the Department of Commerce the commercial standard as shown herein. The standard will become effective for new production and clearance of existing stocks on October 1, 1931.

Promulgation recommended.

Promulgated.

I. J. FAIRCHILD, Chief, Division of Trade Standards.

George K. Burgess, Director, Bureau of Standards.

Approved.

R. P. Lamont, Secretary of Commerce. 


\section{GENERAL}

The following recommendations are offered for the betterment of conditions in the industry and for the protection of the ultimate purchaser against fraudulent practices.

Types, shapes, materials, constructions, colors, finishes, hinges, and general practices given herein are recommended as standard.

Types and finishes above the minimum standard, but not specifically mentioned, shall be considered as special and may be so labeled.

As a standard practice, all manufacturers shall indicate standard types of staple seats for water-closet bowls conforming to the commercial standard by heavy-face type in any new catalogues or literature sent out in the future. If desired, this may be supplemented by a special section of the index referring to standard types and sizes.

\section{NOMENCLATURE}

Seats shall be classified according to finish as: Varnished seats, sprayed (white or colored) finish seats, sheet-covered seats, hard rubber seats, and molded composition seats.

Types of seats shall be designated as staple ring seat, with or without cover, staple open-front seat, with or without cover, and staple openfront and back seat, with or without cover.

The shape of plain-rim staple-ring seats shall be designated as: For staple bowls (round front).

Semi and full saddle patterns shall be considered as specials.

Shapes of open front or open front and back seats shall be designated as: For staple bowls (round front), for staple extended lip bowls, and for staple elongated bowls.

\section{MATERIALS AND CONSTRUCTIONS}

The wood used in the manufacture of varnished, sprayed-finish, or sheet-covered seats shall be of high grade, thoroughly seasoned hardwood according to the classification of the National Hardwood Lumber Association. It shall be free from knots, checks, wormholes, or other injurious defects.

Wood seats shall be reinforced with either steel or wooden splines or dowels. The minimum total length of all doweling shall be not less than 8 inches. The minimum diameter for steel dowels shall be $1 / 4$ inch and for wood $3 / 8$ inch.

Hard rubber or molded composition seats shall be made of a hard rubber or molded composition shell with either hollow or solid core. Solid cores shall be of hard rubber composition, laminated wood or other equally satisfactory material, with a shell or covering of a good grade of hard rubber or molded composition. The shell or covering shall be of the following minimum thicknesses, depending on the core used: 
(a) Hoilow core.-The hard shell shall be at least $3 / 16$ inch in thickness, of which $3 / 6$ inch shall be hard rubber or molded composition covering.

(b) Solid core.-This shall have a hard rubber or molded composition covering with a minimum thickness of $1 / 16$ inch.

All finished seats shall be free from defects in material and workmanship.

All seats shall have at least two rubber bumpers either elongated, mushroom, or round, attached to under side to carry the seat at a minimum distance of $\% / 8$ inch above the bowl.

Covers shall have at least two rubber bumpers attached to underside. The hinge and bumpers shall carry the cover parallel to and at a minimum distance of $3 / 8$ inch a hove the seat.

\section{DIMENSIONS}

Staple seats made from not less than $5 / 4$ hardwood stock and finished to a thickness of not less than $15 / 16$ inch shall be known as $11 / 4^{-}$ inch seats.

Seats made from not less than $6 / 4$ hardwood stock with the wood core finished to a thickness of not less than $13 / 16$ inches shall be known as $1 \frac{1}{2}$ inch seats.

Staple varnished, sprayed (white or colored), and sheet-covered (white or colored) seats shall be made from not less than $5 / 4$ hardwood stock.

Staple hard-rubber or molded-composition seats shall be not less than $11 / 16$ inches in finished thickness.

Covers for staple varnished, sprayed, and sheet-covered seats shall be made from $4 / 4$ hardwood stock and finished to a minimum thickness of $11 / 18$ inch.

Covers for staple hard-rubber or molded-composition seats shall be not less than $5 / 8$ inch in finished thickness.

The size of the seat holes for all seats shall be not less than 9 inches in length and 8 inches in width.

\section{FINISHES}

Varnished seats.-Varnished seats shall be fnished with not less than two coats of finishing material, either lacquer or varnish, after the stain and filler are applied.

Sprayed-finish seats (white or colored).--Sprayed-finish seats (white or colored) finished with pyroxylin lacquer or pyroxylin enamel shall have a minimum thickness of finish of 0.008 inch.

When not otherwise specified finishes for colored seats shall harmonize with the colors of Commercial Standard CS30-31, Colors for Sanitary Ware," designated as SC-11, green; SC-20, orchid; SC-30, ivory; SC-40, blue; SC-51, light brown; and SC-60, black.

Sheet-covered seats.-Sheet-covered seats shall have a sheet of pyroxylin in white or plain colors applied of not less than 0.0125 inch in thickness, and those finished in pearl effect shall have an essence of pearl sheet applied of not less than 0.010 inch in thickness before application regardless of backing.

$62887^{\circ}-31-2$ 
Essence of pearl effect finish shall be considered as standard for pearl-effect covered sheets.

Colors for sheet-covered seats shall be the same as for sprayedfinish colored seats.

\section{FINGES}

The types of hinges shall be known as leaf hinge with bar, concealed hinge with bar, side-arm hinge, and arch hinge.

Hinges shall be made of nickel-plated polished brass. The brass mixture shall contain not less than 61 per cent copper and not more than 5 per cent lead.

The distance between hinge posts shall be $5 \frac{1}{2}$ inches from center to center.

Finge posts shall be provided with 4 rubber and 2 metal washers. Studs shall be not less than 2 inches in length below flange on post. Studs shall be threaded to within 1 inch of flange. Threads shall be U. S. standard-16 threads per inch for $3 / 8$-inch diameter stud or 13 threads per inch for $1 / 2$ inch diameter stud. Nuts for studs shall be not more than 1 inch in maximum diameter.

The bars for bar hinges used on varnished, sprayed, or sheet-covered seats shall be a brass tube at least $7 / 16$ inch in diameter. When not threaded it shall be at least No. 22 B. \& S. gage $(0.025$ inch) and when threaded it shall be at least No. 18 B. \& S. gage (0.040 inch).

The bar for bars hinges used on hard-rubber or molded-composition seats shall be a brass tube or bar at least $5 / 8$ inch in diameter and shall be of same thicknesses as specified for hinges for varnished, sprayed, or sheet-covered seats.

The minimum weights of the various hinge types are specified in Table 1. The total weight of the bar hinges includes the weight of the finished bar, posts, nuts, and seat and cover leaves. The total weight of the side-arm hinge includes the weight of 2 arms, 2 posts, studs, and nuts.

TaBue 1.-Minimum weights of hinges

Typo of hinge
Leaf hinge with bar

1 Not to be used.

All wood screws used in connection with hinges shall be made of brass and at least $5 / 8$ inch in length.

White metal, chromium-plated, colored, or rubber-covered hinges shall be considered as specials. 


\section{LABELS AND GUARANTIES}

It is recommended that all seats bear the name or the trade-mark of the actual manufacturer applied in such manner as to be permanent. All seats shall be permanently labeled with the finish specified as varnished, sprayed, sheet covered, hard rubber, or molded composition.

Printed labels, at least 2 inches wide, g'ummed on one end, shall be attached around the rear of the seat between the hinge posts, and shall bear the following wording, using only one of the five finish designations indicated:

$$
\text { "This }\left\{\begin{array}{l}
\text { varnished } \\
\text { sprayed } \\
\text { sheet-covered } \\
\text { hard-rubber } \\
\text { molded-composition }
\end{array}\right\} \text { seat is guaranteed to conform to }
$$

United States Commercial Standard CS29-31 by the Co.

"Caution.-This label shall be removed only by the ultimate consumer and shall not be used again."

\section{GENERAL CONFERENCE}

Pursuant to a request of the Plumbers' Woodwork Institute, a general conference of all those interested in the production, sale, and procurement of seats for water-closet bowls was held in Chicago, Ill., on December 10, 1930.

After outlining the procedure for the establishment of commercial standards, the proposed commercial standard was read by J. L. Campbell, chairman of the Plumbers' Woodwork Institute.

The standard was discussed in detail and, with certain constructive changes, it was approved by the conference and recommended for general acceptance.

\section{STANDING COMMITTEE}

A standing committee was appointed to represent the manufacturers, distributors, and users of this commodity to consider all comments and suggestions leading to the revision of the specification. At the expiration of one year from the date on which the standard becomes effective, the standing committee will consider what revisions, if any, shall be made to keep the commercial standard up to date.

The following were appointed on the standing committee:

J. S. Hopkrns, chairman, Never-Split Seat Co.

Howard C. Leshie, BRE Manufacturing Co.

A. W. Stedman, Standard Tank \& Seat Co.

Benjamin CadbURy, Hajoca Corporation.

H. W. Holl, Davies Supply Co.

W. J. SpIllant, James B. Clow \& Sons.

J. L. Murphy, National Association of Master Plumbers.

L. E. KERN, American Institute of Architects.

R. KEnNedy Hanson, Plumbers' Woodwork Institutute.

G. W. WrAY, National Bureau of Standards.

\section{EFFECTIVE DATE}

The effective date for new production and for clearance of existing stocks under the commercial standard was fixed at six months after announcement of the formal acceptance of the standard. 


\section{CERTIFICATION PLAN}

The conference voted its approval of the certification plan for application to staple seats for water-closet bowls in accordance with the commercial standard.

The certification plan as applied by the National Bureau of Standa.ds to commercial standards consists in the compilation and distribution of lists of manufacturers who are willing, when requested to do so, to certify to purchasers that products supplied by them comply with all the requirements and tests set forth in nationally recognized commercial standards. The plan is also applied to selected Federal specifications.

These lists are available on request to individual consumers, consumer groups, companies, and in fact to any prospective purchasers, for their guidance.

The benefits now derived from the use of specifications by large consumers are thus made immediately available to the small consumer, with incidental advantage to the larger consumers of convenience in ordering and accepting material with fewerlaboratory tests. The manufacturer also benefits from the well-known economies accompanying "mass production."

The lists of manufacturers "willing to certify" to the quality of certain commodities are made by corresponding with, as nearly as possible, all the manufacturers of that product and listing only those who signify their willingness to certify to the purchaser, when requested to do so, that the commodities delivered actually comply with the commercial stanaiard.

Obviously, the purchaser making use of the lists of "willing-tocertify" manufacturers will select therefrom such manufacturers as are known (or assumed) by him to be reliable.

The trend toward the purchase of materials of certified quality from sources shown on such willing-to-certify lists supplies added incentive to standardization on the part of other producers, and thus the benefits of the certification plan will be felt by purchasers either directly or indirectly, whether or not they make use of the plan themselves.

\section{COMMERCIAL-STANDARDS SERVICE}

Industry has long sensed the need for a wider application and use of specifications developed and approved by nationally recognized' organizations. To assist these bodies and the producers and consumers in securing this result and as a natural outgrowth of the movement toward elimination of waste through simplified practice, the National Bureav of Standards has set up a procedure under which specifications, properly indorsed, may be printed as official publications of the Department of Commerce and promulgated as "commercial standards." This service parallels that of simplified practice in many respects and is available only upon request.

Broadly speaking, the aim is to continue the same character of cooperative service in this field that is being rendered in simplification. The division of trade standards is not designed to act as a standardizing body, nor will it engage in the preparation of specifications. Its service is mainly promotional in character, since its chief mission is to invite attention to a standard or a specification which any branch 
of industry may want to promulgate on a nation-wide basis; to determine its eligibility for promulgation; to publish and broadcast it in the event the prerequisites of procedure have been met, including a satisfactory majority acceptance; to facilitate the application of the certification plan for the assurance and convenience of the purchaser; to provide means for periodic audits of adherence; and to cooperate with the Bureau of Foreign and Domestic Commerce in determining the desire of industry relative to translation and promulgation of such specifications as a basis for foreign commerce.

In general, it may be said that a simplification covers types, sizes, and varieties of a commodity which are retained by industry on the basis of demand, whereas a commercial standard establishes definite requirements as to grade, quality, or dimensional tolerances in addition to any limitation of variety desired and accepted by the industry.

\section{ORGANIZATION AND DUTIES OF STANDING COMMITTEE}

In order to carry on the aims and desires of the industry in the standardization of their product, a standing committee is appointed at the general conference. This committee consists of members from each division of the industry, namely, producers, distributors, and consumers, and thus reflects the well-balanced viewpoint of all concerned.

The members of the committee receive all suggestions regarding the commercial standard, and consider its revision in the event that such action is desirable and mutually beneficial.

If the commercial standard does not warrant revision, it is reaffirmed in its existing form, but if any important changes are found desirable, their adoption is recommended by the committee, whereupon the industry is again solicited for written acceptance of the standard in its revised form.

The committee is in effect a centralizing agency for criticisms and comments regarding the commercial standard and is charged with the responsibility of recommending revisions to keep the standard abreast with current industrial practice.

The proper functioning of the committee requires that, when necessary, its members be willing to attend meetings held at some central place, although in many cases it will be possible to conduct the work by correspondence.

When any deceptions in reference to the commercial standard are reported to the standing committee, it applies moral suasion or such other corrective measures as seem desirable. The Department of Commerce has no "police power" to compel adherence, therefore it is incumbent upon the standing committee to do all in its power to encourage all divisions of the industry to follow the provisions of the commercial standard and contribute in every way possible to its general adoption and usefulness.

\section{YOUR COOPERATION}

As a producer, distributor, or consumer of some of the commodities for which commercial standards have already been established, you are in a position to avail yourself of the benefits arising from the use of quality standards and incidentally to add impetus to this method of eliminating waste. 
The first step is a declaration in favor of the standard by recording your intention to adhere, as closely as circumstances will allow, to the standards for those products which you may buy or sell.

The receipt of your signed acceptance will permit the listing of your company in new editions of the commercial standards that you accept.

You will, of course, want to examine any commercial standards before signing a formal acceptance. The National Bureau of Standards will, therefore, furnish a copy of any standard under consideration for acceptance. To facilitate this procedure, a list appears on page 12 that may be checked and mailed to the division of trade standards, National Bureau of Standards, Washington D. C. The publications may also be secured singly or in quantities at a nominal price from the Government Printing Office. Prices will be furnished upon request.

The acceptance of a commercial standard is an entirely voluntary action and applies to the production, sale, and use of stock items. It is not meant to interfere with the introduction, manufacture, or sale of special sizes and types sometimes required.

Trade associations and individual companies often distribute large numbers of the printed standard for the information and guidance of their members or customers. In such cases it is possible to extend the scope and degree of adherence by urging each recipient to send in an acceptance, bearing in mind that the practical value of any standardization is measured by the observance it receives.

An acceptance form for the commercial standard herein covered is included on page 9. 


\section{ACCEPTANCE OF COMMERCIAL STANDARD}

(Please sign and return this sheet to division of trade standards, National Bureau of Standards, Washington, D. C.)

Date

Division of Trade Standards, National Bureau of Standards, Washington, D. C.

Gentlemen: We, the undersigned, do hereby accept the original draft of the Commercial Standard as our standard practice in the $\left\{\begin{array}{l}\text { production }^{1} \\ \text { distribution }^{1} \\ \text { procurement }^{1}\end{array}\right\} \begin{aligned} & \text { of staple seats for water- } \\ & \text { closet bowls, beginning }\end{aligned}$ (Date) and will use our best effort in securing its general adoption.

To permit intelligent review of the effectiveness of the commercial standard every year by an accredited committee of all interests, working in cooperation with the Department of Commerce, we plan to supply all data, upon request, which may be necessary for the development of constructive revisions. It is understood that any suggested modifications will be submitted as soon as formulated, and shall not be promulgated until accepted in form similar to this recommendation.

Signature

(Kindly typewrite or print the following lines:)

Title

Company

Street address

City and State

We are members of the following associations or other organizations interested in the production, sale, or procurement of staple seats for water-closet bowls:

1 Please designate which group jou represent by drawing lines through the other two. In the case of related interests, trade papers, colleges, etc., desiring to record their genoral approval, the words "in principle" should be added after the signature. 


\section{TO THE ACCEPTOR}

In signing the acceptance blank, please bear the following points clearly in mind:

1. Adherence.-The Department of Commerce has no regulatory powers to enforce adherence to the commercial standards. Instead, this waste-elimination program is based on voluntary cooperation and self-government in industry. To make this specific standardization operate as a satisfactory example of self-government, it is highly desirable that it be kept distinct from any plan or method of governmental regulation or control. It will be successful according to the degree to which manufacturers, distributors, and purchasers adhere to its terms and conditions.

2. The industry's responsibility.-The Department cooperates only on the request of the industry and assumes no responsibility for industrial acceptance or adherence. This program was developed by the industry on its own initiative. Its success depends wholly on the active cooperation of those concerned.

3. The acceptor's responsibility.-You are entering into an entirely voluntary arrangement whereby the members of the industry-the distributors and consumers of the product and others concernedhope to secure the benefits inherent in commercial standardization. Those responsible for this standard realize that instances may occur in which it will be necessary to supply or purchase items not included therein. The purpose is, however, to secure wider support for nationally recognized standards covering grade, quality, and other characteristics of products. Consumers can make the program a success if, in their purchasing they will make a definite and conscientious effort to specify in terms of this commercial standard.

4. The department's responsibility.-The function performed by the Department of Commerce is fourfold: First, to act as a referee to insure adequate consideration of the needs of all interests; second, to supply such assistance and advice in the development of this program as past experience with similar programs may suggest; third, to solicit and record the extent of adoption and adherence to the standard; and fourth, to add all possible prestige to this standardization movement by publication and promulgation if and when it is adopted and accepted by all elements directly concerned. 


\section{REQUEST FOR COMMERCIAL STANDARDS}

Date

Division of Trade Standards,

National Bureau of Standards, Washington, D. C.

Gentlemen: The undersigned wishes to examine the commercial standards checked on the reverse side of this - page, with a view toward accepting them as our standard of practice in the production, distribution, or consumption of the standardized lines.

Signed (Kindly typewrite or print the following lines:)

Title

Company

Street address

City and State 


\section{LIST OF COMMERCIAL STANDARDS}

CS No.

0-30. The commercial standards service and its value to business.

1-28. Clinical thermometers.

2-30. Mop sticks

3-28. Stoddard solvent

4-29. Staple porcelain (all-clay) plumbing fixtures.

5-29. Steel pipe nipples.

6-31. Wrought-iron pipe nipples (first revision)

7-29. Standard weight malleable iron or steel screwed unions.

8-30. Plain and thread plug and ring gage blanks.

9-29. Builders' template hardware.

10-29. Brass pipe nipples.

11-29. Regain of mercerized cotton yarns.

12-29. Domestic and industrial fuel oils.

13-30. Dress patterns.

14-31. Boy's blouses, button-on waists, shirts, and junior shirts.

15-29. Men's pajamas.

16-29. Wall paper.

17-30. Diamond core drill fittings.
CS No.

Item

18-29. Hickory golf shafts.

19-30. Foundry patterns of wood.

20-30. Staple vitreous china plumbing fixtures.

21-30. Interchangeable ground glass joints.

22-30. Builders' hardware (nontemplate).

23-30. Feldspar.

24-30. Standard screw threads.

25-30. Special screw threads.

26-30. Aromatic red cedar closet lining.

27-30. Plate-glass mirrors.

28-32. Cotton fabric tents, tarpaulins, and covers.

29-31. Staple seats for water-closet bowls.

30-31. Colors for colored sanitary ware (in preparation).

31-31. Red cedar shingles (in preparation).

32-31. Cotton goods for rubber and pyroxylin coating (in preparation)

33-32. Knit underwear (exclusive of rayon) (in preparation)

34-31. Bag, case, and strap leather (in preparation).

35-31. Plywood (in preparation). 

